\title{
Physicochemical characteristics and ginsenoside content of Korean traditional wine produced by fermentation of Panax ginseng sprouts
}

\author{
Min-Jung Pyo, A-Ro Cho, Min-Jung Kang, Gyeong-Wha Kim, Jung-Hye Shin* \\ Namhae Garlic Research Institute, Namhae 52430, Korea
}

\section{새싹삼 발효주의 발효기간 중 이화학적 특성 및 진세노사이드 함량변화}

\author{
표민정 · 조아로 · 강민정 · 김경화 · 신정혜* \\ (재) 남해마늘연구소
}

\begin{abstract}
Panax ginseng sprouts are well known for their high ginsenoside content and are free from pesticide contamination. Therefore, we made liquor from Panax ginseng sprouts using different methods of fermentation: using ground Panax ginseng sprouts (GP), using an aqueous extract of Panax ginseng sprouts at $50 \pm 3^{\circ} \mathrm{C}$ (WEP), and using an enzyme hydrolyzed extract of Panax ginseng sprouts (EEP), along with a control reaction using no Panax ginseng sprouts (CO). We evaluated physicochemical characteristics to define the optimal fermentation conditions. Our results showed that acidity, total phenol content, and ABTS radical scavenging activity increased and the pH and reducing sugar content decreased as fermentation progressed. The content of the ginsenoside Re was the highest, followed by Rg1 and Rh1; the other ginsenosides were present in minimal amount. Total ginsenoside content of WEP was higher than that of GP, EEP, and CP on the $6^{\text {th }}$ day of fermentation. These data indicated that the physicochemical changes are similar between the various methods of Panax ginseng sprout liquor fermentation; however, aqueous extracts at $50^{\circ} \mathrm{C}$ are the most ideal substrates to obtain a high ginsenoside content.
\end{abstract}

Key words : Panax ginseng sprout, traditional fermented wine, ginsenoside, antioxidant activity

\section{서 론}

동양의 대표적인 영약인 인삼(Panax ginseng C. A Meyer)은 오가과(Araliaceae) 인삼속에 속하는 식물로 다양 한 약리효과를 가지고 있어 다방면으로 이용되고 있다(1). 특히 우리나라가 생산하는 고려인삼은 전 세계적으로 그 효능이 우수하다고 알려져 있다(2). 인삼은 한의학적으로 주로 기허(幾許)에 사용하는 중요한 보기약(補氣藥)으로 알 려져 있으며, 중국을 비롯한 여러 동양권의 한방의서에 수 록되어 체력증강, 피로회복, 소화기계, 신경계, 대사계 순환 기계 등의 기능조절을 위해 단독 또는 처방의 구성 생약으

*Corresponding author. E-mail : whanbee@hanmail.net Phone : 82-55-860-8947, Fax : 82-55-860-8960

Received 17 July 2018; Revised 29 August 2018; Accepted 30 August 2018.

Copyright (c) The Korean Society of Food Preservation. All rights reserved.
로 활용된다(3).

인삼은 노지에서 5-6년 이상 재배하여 상품이 되며, 사포 닌, 폴리페놀, 폴리아세틸렌, 알칼로이드 등이 함유되어 있 고, 그 중에서 사포닌은 진세노사이드라고 불리며, 그 종류 가 30 가지에 이르는데 항산화 작용, 면역증강, 동맥경화와 고혈압 예방(4), 항염증(5) 등 매우 다양한 효능이 알려져 있다. 진세노사이드는 인삼의 뿌리뿐만 아니라 줄기, 잎 등의 부산물에도 다량으로 함유되어 있는데, 인삼 뿌리에 는 $4.45 \%$, 인삼 잎 $12.8-18.7 \%$, 인삼 꽃 $6.9 \%$, 인삼 열매 $6.68 \%$, 인삼 줄기 $1.6-2.39 \%$, 인삼 씨앗에는 $3.3 \%$ 로 인삼 뿌리에 비해 인삼 잎, 꽃, 줄기는 2-4배 정도로 많은 사포닌 을 함유하고 있는 것으로 알려져 있으나(6-8), 인삼은 재배 기간 동안에 모잘록병, 뿌리썩음병, 점무늬병, 잿빛 곰팡이 병, 탄저병 등과 같은 많은 병충해에 감염되므로 다량의 농약을 사용하여 뿌리 이외의 부산물은 이용하지 못하고 폐기하고 있는 실정이다(9).

이에 반해, 새싹삼은 수경재배를 통해 1년 정도 키운 묘 
삼을 배양토에 이식하여 2개월 정도 키운 것으로 농약 없이 재배하기 때문에 뿌리부터 줄기, 잎 모두 섭취 및 이용 가능 하여 최근 새싹삼에 대한 인기가 높아지고 있다(10). 최근에 는 수확시기에 따른 새싹삼의 부위별 생육 및 ginsenoside 함량변화를 확인한 연구(11)와 새싹삼의 이용가공과 관련 하여 굴과 새우를 이용한 새싹삼 페이스트의 품질특성에 대한 연구(12), 새싹인삼을 첨가한 카스텔라의 품질특성 (13)에 대한 연구가 진행되어 있다.

진세노사이드는 인삼의 재배 조건에 따라 함량에 차이가 나타난다고 알려져 있으나, 대부분의 인삼은 진세노사이드 $\mathrm{Rg} 1, \mathrm{Rb} 1, \mathrm{Rb} 2, \mathrm{Rc}$, 및 $\mathrm{Re}$ 를 주로 함유하고 있다고 알려져 있는데, 이 중 $\mathrm{Re}, \mathrm{Rd}, \mathrm{Rg} 1$ 등이 전체 사포닌의 $70 \%$ 이상을 차지하며, 비교적 분자량이 적은 저분자 진세노사이드 Rh1, $\mathrm{Rg} 2$, 및 $\mathrm{Rg} 3$ 는 거의 함유하지 않는다(14). 진세노사이드 $\mathrm{Rh} 1, \mathrm{Rg} 2$, 및 $\mathrm{Rg} 3$ 는 증숙, 발효 및 산처리 등의 가공을 거쳐야 생성되는 이차적 물질로서 인삼유가 함유한 본래의 고분자 진세노사이드의 화학적 변환에 의해 생성되므로 (15) 항염증 효과, 항노화 효과, 암세포 전이 억제효과 등 약리적 활성이 강한 진세노사이드 Rg3를 증가시키고자 효 모 등 미생물의 초산발효나 백삼을 홍삼으로 증숙하는 공정 을 적용하는 연구들이 진행되고 있다(16,17). 하지만 백삼 추출물을 양조식초에서 $90^{\circ} \mathrm{C}$ 를 유지한 채 11 시간 반응시켜 놓은 경우 Rg3의 함량은 최대로 $4.5 \%$ 를 나타내지만 24시간 후에는 유기산의 영향으로 전체 진세노사이드의 분해를 가속화 시키는 효과가 유발된다는 보고(17)도 있어 다양한 발효 조건에서 진세노사이드의 함량의 변화에 대한 연구들 이 더 추진되어야 한다.

따라서 본 연구에서는 새싹삼을 이용한 발효 가공품 개 발의 기초자료를 확보하고자 3 단 담금 공정을 통해 발효주 를 제조한 후 전처리 방법을 달리한 새싹삼을 첨가하여 숙성시키면서 phenolic compound와 진세노사이드를 중심 으로 한 주요 성분의 변화와 항산화 활성의 변화를 분석하 였다.

\section{재료 및 방법}

\section{발효주 제조용 재료}

새싹삼은 개체당 무게 $4.5 \pm 0.8 \mathrm{~g}$, 길이 $50 \pm 5 \mathrm{~cm}$ 정도의 것을 고성 공룡엑스포 영농조합법인으로부터 제공받아 흐 르는 물에서 세척하여 자연건조 한 다음 전체를 분쇄하여 시료로 사용하였다. 발효주의 최종 분량 대비 $3 \%$ 의 새싹삼 을 함유하도록 분량의 새싹삼 분쇄물에 무게 대비 20 배의 물을 가한 후 $50 \pm 2^{\circ} \mathrm{C}$ 에서 6 시간 동안 가열하여 저온 추출물 을 제조하였다. 효소분해 추출액은 저온 추출물과 동일한 분량의 새싹삼 분쇄물과 정제수를 혼합한 다음 viscozyme (Novozyme, Bagasvaerd, Copenhagen, Denmark) $0.75 \%$ 와
fungamyl(Novozyme)을 $0.25 \%$ 혼합한 효소액을 전체 부피 대비 $1 \%$ 첨가하여 $50 \pm 2^{\circ} \mathrm{C}$ 에서 24 시간 동안 효소 분해하여 제조하였다.

새싹삼 발효주 제조를 위한 누룩은 세척하여 3-4시간 불려서 물빼기한 후 분쇄한 다음 무게 대비 $10 \%$ 정도의 수분을 함유하도록 조정하고 여기에 Rhyzopus oryzae 포자 를 접종하여 고루 혼합하여 두께 $3-5 \mathrm{~cm}$ 정도로 만들어 한지로 포장하여 실온에서 20 일 정도 띄워 제조하였다. 띄 우기가 완성된 누룩은 표면의 균사체를 털어내고 분쇄하여 사용하였으며 정제수는 시판되고 있는 삼다수를 구입하여 사용하였다. 지에밥 제조를 위한 쌀은 무게 비율로 찹쌀과 멥쌀을 2:8로 혼합하여 사용하였다. 분량의 쌀을 세척한 후 5 시간 동안 불림처리 한 다음 40 분 동안 증숙하여 고두밥 을 제조해 $50^{\circ} \mathrm{C}$ 정도로 식혀서 사용하였다.

\section{새싹삼 발효주의 제조 및 숙성}

새싹삼 발효주는 3 단 발효를 통해 제조하였다. 1 단계에 서는 가열 살균한 맥아 추출액에 Saccharomyces cerevisiae 를 접종하여 $30^{\circ} \mathrm{C}$ 에서 2 일간 증식시킨 주모, 누룩 및 정제수 를 25:400:500의 무게비로 혼합한 후 $30^{\circ} \mathrm{C}$ 에서 2 일간 발효 하였다. 이어 2 단계 발효에서는 1 단 담금된 시료에 누룩 $70 \mathrm{~g}$ 과 지에밥 $480 \mathrm{~g}$ 을 추가한 후 정제수 $1,000 \mathrm{~g}$ 을 가하여 $25^{\circ} \mathrm{C}$ 에서 2 일간 발효하였다. 3 단계에서는 2 단계 발효 시와 동일한 양의 누룩, 지에밥과 정제수에 새싹삼 저온추출액 과 효소 분해액을 각각 가하고, 분쇄물 첨가군은 분량의 분쇄물에 용수만을 가하여 각각을 혼합한 후 $20^{\circ} \mathrm{C}$ 에서 6 일 간 발효시켰다. 이 때 동일한 방법으로 용수에 새싹삼을 첨가하지 않은 것을 대조군으로 하였다. 1,2 단계 발효에서 는 담금 직후와 숙성 2 일에 각각 시료를 취하였고, 3 단계 발효에서는 담금 직후와 숙성 기간 동안 2 일 간격으로 시료 를 취하였다.

\section{알코올 농도, $\mathrm{pH}$ 및 산도}

알코올 농도는 국세청 주류분석규정(18)에 따라 측정하 였다. $500 \mathrm{~mL}$ 둥근 플라스크에 $100 \mathrm{~mL}$ 의 시료를 취한 후 수증기 증류하여 증류액이 $60 \mathrm{~mL}$ 가 되면 증류수를 가해 $100 \mathrm{~mL}$ 로 정용하여 잘 혼합한 다음 디지털 주정계(MT-830, Atago Co., Ltd., Tokyo, Japan)로 측정하였다.

$\mathrm{pH}$ 와 산도는 시료액 $1 \mathrm{~mL}$ 를 취하여 자동적정기(G20 compact titrator, Mettler toledo, Langacher, Greifensee, Switzerland)를 이용해 동시에 분석하였다.

\section{환원당}

Dinitrosalicylic acid(DNS)법에 따라 증류수로 희석한 시 료 액 $1 \mathrm{~mL}$ 에 DNS시약 $3 \mathrm{~mL}$ 을 가한 후 끓는 물에서 15 분간 중탕 가열 한 다음 빙수 중에서 냉각하였다. 이것을 분광광 도계(Libra S 35, Biochrom Ltd., Cambridge, England)로 570 
$\mathrm{nm}$ 에서 흡광도를 측정하여 glucose(Sigma-Aldrich Co., St, Louis, MO, USA)를 표준물질로 한 검량곡선에 따라 정량하 였다.

\section{총 페놀 화합물 함량}

총 페놀 화합물의 함량은 폴리페놀성 물질인 phosphomolybdic acid와 반응하여 청색을 나타내는 원리로 Folin-Denis 법(19)에 따라 시료 추출 여액 $1 \mathrm{~mL}$ 에 Folin-Ciocalteau 시약 $0.5 \mathrm{~mL}$ 를 넣고 3 분간 충분히 교반한 다음 $10 \% \mathrm{Na}_{2} \mathrm{CO}_{3}$ 용액을 $0.5 \mathrm{~mL}$ 를 가하여 실온의 암실에서 1 시간 정치한 후 $760 \mathrm{~nm}$ 에서 흡광도를 측정하였다. 표준물 질로 gallic acid(Sigma-Aldrich Co.)를 사용하여 시료와 동 일한 방법으로 분석하여 얻은 검량선으로부터 총 페놀 화합 물의 함량을 계산하여 gallic acid equivalent(mg GAE/g)로 표기하였다.

\section{진세노사이드 정량}

시료 $3 \mathrm{~g}$ 에 $30 \mathrm{~mL}$ 의 $50 \% \mathrm{MeOH}$ 을 첨가한 후 15 분 동안 초음파 추출하여 여과하였다. Sep-Pak Plus $\mathrm{C}_{18}$ cartridge에 $\mathrm{MeOH} 3 \mathrm{~mL}$ 를 서서히 용출시켜 conditioning 하고 다시 3 $\mathrm{mL}$ 의 증류수로 2 차 conditioning 시켰다. 추출 시료액 2 $\mathrm{mL}$ 을 cartridge에 loading하고 $10 \mathrm{~mL}$ 증류수로 서서히 용출 하여 당류 등을 제거하였다. 메탄올 $2 \mathrm{~mL}$ 를 처리하여 진세 노사이드를 용출한 후 $0.45 \mu \mathrm{m}$ membrane filter로 여과하였 다. 진세노사이드 함량은 HPLC-DAD(Agilent 1260, Agilent Technologies, Santa clara, CA, USA)로 분석하였다. 분석 컬럼은 Agilent Zorbax SB-C ${ }_{18}(4.6 \times 250 \mathrm{~mm}, 5 \mu \mathrm{m}$, Agilent Technologies)를 사용하고, 이동상의 유속은 $0.8 \mathrm{~mL} / \mathrm{min}$, 컬럼 온도는 $40^{\circ} \mathrm{C}, \mathrm{UV}$ 검출기의 검출파장은 $203 \mathrm{~nm}$ 로 분석 하였다. 이동상은 water(A)와 acetonitrile(B)를 사용하여 서 로의 비율을 70:30-5:95로 변화시키면서 유속을 $0.8 \mathrm{~mL} / \mathrm{min}$ 로 조정하여 70 분간 분석하였다. 표준물질로 10 종의 진세 노사이드(Sigma-Aldrich Co.)를 사용하여 시료와 동일한 방 법으로 분석하여 얻은 검량선으로부터 함량을 계산하였다.

\section{항산화활성}

항산화활성은 1,1-diphenyl-2-picrylhydrazyl(DPPH)와 2,2'- azino-bis(3-ethylbenzothiazoline-6-sulphonic acid)(ABTS) radical 소거활성을 통해 평가하였다. DPPH radical 소거활 성은 $\mathrm{DPPH}$ 에 대한 전자공여 활성으로 나타낸 것으로 시료 의 항산화 활성이 높을수록 보라색이 탈색되는 원리를 이용 한 Blois(20)의 방법을 변형하여 측정하였다. 에탄올로 $1.5 \times 10^{-4} \mathrm{M}$ 농도가 되도록 조절한 $\mathrm{DPPH}$ 용액 $100 \mu \mathrm{L}$ 와 시료 $100 \mu \mathrm{L}$ 를 혼합한 다음 실온에서 20분간 반응시킨 후 $525 \mathrm{~nm}$ 에서 흡광도를 측정해 시료 무첨가구에 대한 시료첨 가구의 흡광도비로 계산하여 \%로 나타내었다.

$\mathrm{ABTS}$ radical 소거활성은 $\operatorname{Re}$ 등(21)의 방법에 따라 7 $\mathrm{mM}$ ABTS 용액에 potassium persulfate를 $2.4 \mathrm{mM}$ 이 되도록 용해시킨 다음 암실에서 12-16시간 동안 반응시킨 후 415 $\mathrm{nm}$ 에서 흡광도가 1.5 가 되도록 증류수로 희석하였다. 이 용액 $100 \mu \mathrm{L}$ 에 농도별 시료액을 $100 \mu \mathrm{L}$ 가하여 실온에서 5 분간 반응시킨 후 $415 \mathrm{~nm}$ 에서 흡광도를 측정하였으며, ABTS radical 소거능은 시료첨가구와 무첨가구의 흡광도 비로 나타내었다.

\section{통계처리}

모든 실험은 3회 이상 반복하여 실시하였으며 실험으로 부터 얻은 결과는 SPSS 18.0(IBM Corporation, Endicott, $\mathrm{NY}, \mathrm{USA})$ 을 사용하여 분석하였다. 결과치는 실험군당 평 균 \pm 표준편차로 표시하였고, 통계적 유의성 검정은 일원배 치 분산분석 한 후 $\mathrm{p}<0.05$ 수준에서 Duncan's multiple range test를 시행하였다.

\section{결과 및 고찰}

\section{담금 중 이화학적 특성}

발효주를 3 단계로 나누어 증량함에 있어 각 단계마다 2 일간 숙성시키면서 이화학적 특성을 분석한 결과는 Table 1 과 같다. 알코올 함량은 발효주 담금 1 단계 숙성 2 일째에 $15.00 \%$ 였고, 담금 2 단계 숙성 2 일째에 $10.00 \%$, 담금 3 단계 숙성 2 일째에는 $13.00 \%$ 로 발효주의 담금이 성공적으로 진 행됨을 알 수 있었다.

발효주 담금 1 단계 숙성 전의 $\mathrm{pH}$ 는 6.67 에서 2 일 숙성

Table 1. Changes in physicochemical characteristics of wine mashing step added with Panax ginseng sprout from different pre-treatment condition

\begin{tabular}{ccccccc}
\hline & \multicolumn{2}{c}{$1^{\text {st }}$ fermentation step } & \multicolumn{2}{c}{$2^{\text {nd }}$ fermentation step } & \multicolumn{2}{c}{$3^{\text {rd }}$ fermentation step } \\
\hline Fermentation periods (days) & 0 & 2 & 0 & 2 & 0 & 2 \\
\hline Alcohol contents (\%) & - & $15.00 \pm 0.20^{\mathrm{ll}}$ & $5.00 \pm 0.10^{\mathrm{a}}$ & $10.00 \pm 0.30^{\mathrm{c}}$ & $7.00 \pm 0.10^{\mathrm{b}}$ & $13.00 \pm 0.20^{\mathrm{d}}$ \\
$\mathrm{pH}$ & $6.67 \pm 0.26^{\mathrm{c}}$ & $4.70 \pm 0.07^{\mathrm{b}}$ & $6.70 \pm 0.41^{\mathrm{c}}$ & $3.77 \pm 0.01^{\mathrm{a}}$ & $3.98 \pm 0.02^{\mathrm{a}}$ & $3.86 \pm 0.02^{\mathrm{a}}$ \\
Acidity (\%) & $0.16 \pm 0.01^{\mathrm{a}}$ & $0.38 \pm 0.05^{\mathrm{b}}$ & $0.17 \pm 0.03^{\mathrm{a}}$ & $0.87 \pm 0.02^{\mathrm{d}}$ & $0.64 \pm 0.02^{\mathrm{c}}$ & $0.69 \pm 0.03^{\mathrm{c}}$ \\
Reducing sugar (g/100 g) & $3.36 \pm 0.03^{\mathrm{e}}$ & $1.26 \pm 0.02^{\mathrm{b}}$ & $3.52 \pm 0.14^{\mathrm{f}}$ & $2.23 \pm 0.04^{\mathrm{d}}$ & $1.95 \pm 0.04^{\mathrm{c}}$ & $0.82 \pm 0.02^{\mathrm{a}}$ \\
\hline
\end{tabular}

1)arf Means with different superscripts within the same row are significantly different by Duncan's multiple range test $(\mathrm{p}<0.05)$. 
후 4.70 으로 떨어졌으며, 2단 담금에서 $\mathrm{pH}$ 는 6.70 에서 2일 후 3.77 로 감소한 이후, 담금 3 단계에는 숙성 전후의 $\mathrm{pH}$ 에 유의적 차이가 없었다. 이는 $\operatorname{Jang}(22)$ 의 연구에서 시판약주 의 $\mathrm{pH}$ 는 발효초기에 저하되지만, 이후에는 $\mathrm{pH} 4.0$ 이하로 안정적으로 유지된다는 보고와 동일한 경향이었다.

발효주 담금 단계에서의 산도는 담금 2 단계에서 숙성 전 $0.17 \%$ 이던 것이 숙성 2 일 후 $0.87 \%$ 로 증가하여 그 변화 폭이 가장 컸다. 반면 담금 3 단계에는 숙성 전에는 산도가 $0.64 \%$ 에서 숙성 2 일 후에는 $0.69 \%$ 로 차이가 없었다. 이러 한 결과는 발효주의 발효 초기에 총산의 함량이 급격히 증가하며 그 이후에는 변화가 미미하였다는 So 등(23)의 연구결과와 유사하였다.

알코올 발효에서 원료 중 전분은 당화 amylase작용에 의해서 큰 전분분자가 작은 전분분자로 분해되고 다시 glucose로 분해되어 알코올 발효의 기질로 이용되며, 감미 도에 관여하는 중요한 성분이다(24). 발효주 담금 1 단계에 서 숙성 전에 환원당의 함량은 $3.36 \mathrm{~g} / 100 \mathrm{~g}$ 에서 숙성 2 일 후 $1.26 \mathrm{~g} / 100 \mathrm{~g}$ 으로 변화하였고, 발효주 담금 2단계에서는 숙성 전 $3.52 \mathrm{~g} / 100 \mathrm{~g}$ 에서 숙성 2 일 후 $63.4 \%$ 정도가 잔존하 였고, 담금 3단계에서는 $1.95 \mathrm{~g} / 100 \mathrm{~g}$ 에서 $0.82 \mathrm{~g} / 100 \mathrm{~g}$ 으로 감소하였다. 이러한 변화는 담금이 진행됨에 따라 발효주 의 환원당이 알코올 발효되었기 때문으로 생각되는데, 1 단 담금 후 환원당 함량이 가장 큰 폭으로 감소하여 2 일 숙성 후 잔존율은 약 $37.5 \%$ 로 발효가 가장 활발히 진행된 것으로 추정된다.

\section{발효주 숙성 중 알코올의 함량변화}

새싹삼 발효주의 3 단 담금 후 숙성 기간 동안 알코올 함량의 변화는 Table 2 와 같다. 새싹삼 발효주의 알코올 함량은 숙성기간 동안 증가하는 경향이었으나 숙성 4 일과 6 일에는 알코올 함량 차이가 없어 숙성 4 일이 지나면서 알코올 발효는 종료된 것으로 판단된다. 새싹삼 발효주의

Table 2. Changes in alcohol contents of fermented wine added with Panax ginseng sprout from different pre-treatment condition

$(\%)$

\begin{tabular}{ccccc}
\hline \multirow{2}{*}{ Sample code $^{1)}$} & \multicolumn{4}{c}{ Fermentation periods (days) } \\
\cline { 2 - 5 } & 0 & 2 & 4 & 6 \\
\hline CO & $8.50 \pm 0.20^{22) A 3}$ & $11.03 \pm 0.80^{\mathrm{bB}}$ & $12.13 \pm 0.50^{\mathrm{CA}}$ & $12.10 \pm 0.53^{\mathrm{CA}}$ \\
GP & $8.20 \pm 0.30^{\mathrm{aA}}$ & $10.50 \pm 0.20^{\mathrm{bAB}}$ & $11.50 \pm 0.20^{\mathrm{cA}}$ & $12.03 \pm 0.31^{\mathrm{dA}}$ \\
WEP & $8.00 \pm 0.36^{\mathrm{aA}}$ & $10.03 \pm 0.21^{\mathrm{bA}}$ & $11.50 \pm 0.40^{\mathrm{cA}}$ & $11.80 \pm 0.60^{\mathrm{cA}}$ \\
EEP & $9.03 \pm 0.21^{\mathrm{aB}}$ & $10.50 \pm 0.40^{\mathrm{bAB}}$ & $11.50 \pm 0.20^{\mathrm{cA}}$ & $11.80 \pm 0.40^{\mathrm{cA}}$ \\
\hline
\end{tabular}

${ }^{1)} \mathrm{CO}$, not added Panax ginseng sprout; GP, added grind Panax ginseng sprout; WEP, added low temperature $\left(50 \pm 3^{\circ} \mathrm{C}\right)$ extract of Panax ginseng sprout; EEP, added enzyme hydrolyzed extract of Panax ginseng sprout.

2)a-c Means with different superscripts within the same row are significantly different by Duncan's multiple range test $(p<0.05)$.

${ }^{3) A-B}$ Means with different superscripts within the same column are significantly different by Duncan's multiple range test $(p<0.05)$.
알코올 함량은 3단 담금 후 8.00-9.03\%이던 것이 숙성 2일 째에는 10.03-11.03\%로 가장 큰 폭으로 증가하였는데, 이는 일반 탁주 발효의 경우 2단 담금 후 4-7일에 알코올 생성량 이 급격히 증가 또는 정점에 도달한다는 $\operatorname{Kim}(27)$ 의 보고와 일치하였다. 숙성 6 일에는 새싹삼의 첨가 여부나 첨가 형태 에 관계없이 시료간의 알코올 함량은 유의적인 차이가 없었 다. 이는 오이를 첨가한 막걸리와 오이를 첨가하지 않고 만든 막걸리의 알코올 함량이 각각 $16.3 \%$ 와 $16.2 \%$ 로 유의 적인 차이가 없었다는 $\mathrm{Kim}$ 등(28)의 보고와 일치하는 경향 이었으며 이로 미루어 보아 새싹삼이 발효주의 알코올 발효 및 함량변화에 영향을 미치지 않음을 알 수 있었다.

\section{발효주 숙성 중 $\mathrm{pH}$ 및 산도의 변화}

전통 약주의 $\mathrm{pH}$ 는 3.51-4.56으로 범위가 넓은 것으로 보 고되어 있다(29). 술에 함유되어 있는 약간의 산은 관능적 기호도를 높이며 술덧 발효에서 잡균의 번식을 억제하는데 긍정적인 영향을 미치지만 약주와 탁주의 술덧은 산도의 변화가 적은 것이 정상이며, 이상발효 시 유해세균의 오염 으로 인해 산도가 급격히 상승하게 된다(30).

새싹삼 발효주의 $\mathrm{pH}$ (Table 3)는 숙성 전 모든 시료에서 4.10-4.18의 범위였다. $\mathrm{CO}$ 는 숙성 기간 동안 $\mathrm{pH}$ 에 유의적 차이가 없었으나, 여타의 새싹삼 첨가 시료들은 감소하는 경향이다가 숙성 6일째에 $\mathrm{pH}$ 가 가장 낮았으나 새싹삼 첨가 시료간의 차이는 없었다.

Table 3. Changes in $\mathrm{pH}$ of fermented wine added with Panax ginseng sprout from different pre-treatment condition

\begin{tabular}{ccccc}
\hline \multirow{2}{*}{ Sample code $^{1)}$} & \multicolumn{4}{c}{ Fermentation periods (days) } \\
\cline { 2 - 5 } & 0 & 2 & 4 & 6 \\
\hline CO & $4.10 \pm 0.17^{\mathrm{a} 2 \mathrm{~A} 3 \mathrm{~B})}$ & $4.17 \pm 0.01^{\mathrm{aB}}$ & $4.17 \pm 0.03^{\mathrm{aB}}$ & $4.12 \pm 0.06^{\mathrm{aB}}$ \\
GP & $4.13 \pm 0.08^{\mathrm{bA}}$ & $4.05 \pm 0.01^{\mathrm{aA}}$ & $4.06 \pm 0.02^{\mathrm{aA}}$ & $4.00 \pm 0.04^{\mathrm{aA}}$ \\
WEP & $4.13 \pm 0.01^{\mathrm{bA}}$ & $4.16 \pm 0.06^{\mathrm{bB}}$ & $4.14 \pm 0.01^{\mathrm{BB}}$ & $4.03 \pm 0.01^{\mathrm{AA}}$ \\
EEP & $4.18 \pm 0.01^{\mathrm{bA}}$ & $4.18 \pm 0.01^{\mathrm{bB}}$ & $4.18 \pm 0.03^{\mathrm{bB}}$ & $4.04 \pm 0.02^{\mathrm{aA}}$ \\
\hline
\end{tabular}

${ }^{1)} \mathrm{CO}$, not added Panax ginseng sprout; GP, added grind Panax ginseng sprout; WEP, added low temperature $\left(50 \pm 3^{\circ} \mathrm{C}\right)$ extract of Panax ginseng sprout; EEP, added enzyme hydrolyzed extract of Panax ginseng sprout.

${ }^{2) a-b}$ Means with different superscripts within the same row are significantly different by Duncan's multiple range test $(\mathrm{p}<0.05)$.

${ }^{3 A-B}$ Means with different superscripts within the same column are significantly different by Duncan's multiple range test $(\mathrm{p}<0.05)$.

새싹삼 발효주의 숙성 중 산도 변화는 다음 Table 4와 같으며 전체적으로 증가하는 양상을 보여 $\mathrm{pH}$ 가 감소하는 것과 상반된 결과였다. $\mathrm{CO}$ 에서는 숙성 2 일에 산도는 증가 하였지만 $\mathrm{pH}$ 는 유의적 차이가 없었는데, 이는 발효주의 숙성으로 인한 단백질 분해로 펩티드와 아미노산이 증가하 여 발효주의 완충능력을 높여 주었기 때문인 것으로 판단된 다(31). 새싹삼 첨가 발효주 중 $\mathrm{GP}$ 는 발효기간 동안 산도가 $\mathrm{CO}$ 와 유의차가 없었으나, 새싹삼 분쇄물을 첨가한 WEP와 
$\mathrm{EEP}$ 는 발효 0 일과 6일에는 $\mathrm{CO}$ 보다 유의적으로 높았다.

Lee 등(32)은 보통의 상품으로서 발효주의 $\mathrm{pH}$ 는 4.2 내외 이며, 유기산을 $0.8 \%$ 포함하고 있다고 하였는데, 본 연구에 서 새싹삼 발효주의 $\mathrm{pH}$ 는 평균 4.12 , 산도는 $0.6 \%$ 로 상품으 로서의 발효주 수준에 부합되었다.

Table 4. Changes in acidity of fermented wine added with Panax ginseng sprout from different pre-treatment condition

$(\%)$

\begin{tabular}{ccccc}
\hline \multirow{2}{*}{ Sample code } & \multicolumn{4}{c}{ Fermentation periods (days) } \\
\cline { 2 - 5 } & 0 & 2 & 4 & 6 \\
\hline CO & $0.53 \pm 0.04^{\mathrm{a} 2) \mathrm{A} 3)}$ & $0.64 \pm 0.03^{\mathrm{bC}}$ & $0.59 \pm 0.06^{\mathrm{abA}}$ & $0.59 \pm 0.06^{\mathrm{abA}}$ \\
GP & $0.54 \pm 0.02^{\mathrm{aA}}$ & $0.62 \pm 0.02^{\mathrm{bBC}}$ & $0.62 \pm 0.02^{\mathrm{bA}}$ & $0.63 \pm 0.04^{\mathrm{bAB}}$ \\
WEP & $0.61 \pm 0.01^{\mathrm{bB}}$ & $0.57 \pm 0.01^{\mathrm{aA}}$ & $0.62 \pm 0.01^{\mathrm{cA}}$ & $0.65 \pm 0.01^{\mathrm{dB}}$ \\
EEP & $0.60 \pm 0.01^{\mathrm{BB}}$ & $0.58 \pm 0.01^{\mathrm{aAB}}$ & $0.59 \pm 0.02^{\mathrm{aA}}$ & $0.65 \pm 0.02^{\mathrm{bB}}$ \\
\hline
\end{tabular}

${ }^{1)} \mathrm{CO}$, not added Panax ginseng sprout; GP, added grind Panax ginseng sprout; WEP, added low temperature $\left(50 \pm 3^{\circ} \mathrm{C}\right)$ extract of Panax ginseng sprout; EEP, added enzyme hydrolyzed extract of Panax ginseng sprout.

2)a-d Means with different superscripts within the same row are significantly different by Duncan's multiple range test $(\mathrm{p}<0.05)$.

3)A-C Means with different superscripts within the same column are significantly different by Duncan's multiple range test $(\mathrm{p}<0.05)$.

\section{발효주 숙성 중 환원당 변화}

새싹삼 발효주의 3 단 담금 후 숙성 중 환원당 변화를 분석한 결과는 Table 5와 같았다. 3 단 담금 후 전처리 방법을 달리한 새싹삼을 첨가한 직후 발효주의 환원당 함량은 숙성 0일에 $\mathrm{EEP}$ 에서 $484.17 \mathrm{mg} / 100 \mathrm{~g}$ 으로 가장 높았다.

Park 등(33)은 셀룰로오스가 viscozyme과 fungamyl과 같 은 가수분해효소에 의해서 글루코오스로 가수분해된다고 하였는데 이와 같은 원리로 새싹삼을 효소분해 하는 동안 함유되어 있던 식물성 다당류가 분해되어 글루코오스와 같은 단당류로 전환됨으로 인해 다른 형태의 새싹삼 첨가군 들에 비해 환원당 함량이 더 높아진 것으로 생각된다.

새싹삼 발효주의 숙성 동안 환원당 함량은 점차 감소하 였는데 숙성 6일에 잔존율은 28.6-38.2\%였으며, 환원당 함
량이 가장 높았던 $\mathrm{EEP}$ 군에서 $170.21 \mathrm{mg} / 100 \mathrm{~g}$ 으로 가장 높은 함량이었고 여타 실험군 간에는 환원당 함량에 유의적 인 차이가 없었다. 알코올 발효에서 환원당 함량은 발효가 진행됨으로 인해 그 함량이 급격히 감소하는데, 알코올의 생성량이 많을수록 환원당의 잔존율이 낮았다는 보고(34) 는 본 연구의 결과와 동일한 경향이었다.

\section{3단 담금 후 숙성 중 총 페놀 화합물의 변화}

페놀 화합물은 phenolic hydroxy기를 가진 식물체 유래의 대사산물로, 단백질 등의 거대분자들과 결합하려는 성질을 가지고 있어, 항산화 효과 등의 생리활성을 가진다고 알려 져 있다(35). 식품에서 phenol 화합물은 2차 대사산물로서, 총 페놀 함유량이 증가함에 따라 항산화 활성이 상승하는 상관관계 속에 있으므로 항산화 활성에 간접적인 지표로 활용 된다(36).

새싹삼 발효주의 숙성 기간 중 총 페놀 화합물의 함량 변화는 Table 6과 같다. 페놀 화합물의 함량은 모든 새싹삼 발효주에서 숙성 기간이 경과함에 따라 점차 증가하는 경향 이었다. 숙성 기간 중 총 페놀 화합물의 함량 증가폭이 가장 높았던 새싹삼 무첨가 대조군 $(\mathrm{CO})$ 은 숙성 전 총 페놀 화합 물의 함량이 $29.15 \mathrm{mgGAE} / 100 \mathrm{~g}$ 이었는데 6일간 숙성 후에 는 약 1.3 배가 증가한 $37.19 \mathrm{mgGAE} / 100 \mathrm{~g}$ 이었다. 6 일 숙성 후 총 페놀 화합물의 함량은 $\mathrm{EEP}$ 군과 $\mathrm{CO}$ 군은 유의적인 차이가 없었으며, 이들에 비해 유의적으로 함량이 낮은 GP 군과 $\mathrm{WEP}$ 군은 각각 $35.30 \mathrm{mgGAE} / 100 \mathrm{~g}$ 과 35.36 $\mathrm{mgGAE} / 100 \mathrm{~g}$ 으로 서로 간에는 유의차가 없었다.

발효가 진행되는 동안 총 페놀 화합물의 함량이 증가한 것은 누룩으로부터 유래된 미생물의 효소작용으로 인해 유리형 phenolics가 증가하기 때문(25)으로 추정된다.

\section{3단 담금 후 숙성 중 진세노사이드의 변화}

3단 담금 후 전처리 조건을 달리한 새싹삼을 첨가해 제조 한 발효주의 숙성 중 진세노사이드의 함량 변화는 Table 7과 같다. 새싹삼 발효주에서 진세노사이드는 $\operatorname{Re}$ 가 가장

Table 5. Changes in reducing sugar content of fermented wine added with Panax ginseng sprout from different pre-treatment condition $(\mathrm{mg} / 100 \mathrm{~g})$

\begin{tabular}{ccccc}
\hline \multirow{2}{*}{ Sample code ${ }^{1)}$} & \multicolumn{4}{c}{ Fermentation periods (days) } \\
\cline { 2 - 5 } & 0 & 2 & $156.77 \pm 2.31^{\mathrm{bB}}$ & 6 \\
\hline CO & $312.08 \pm 6.92^{\mathrm{d}) \mathrm{A} 3)}$ & $229.06 \pm 4.06^{\mathrm{CB}}$ & $145.73 \pm 2.16^{\mathrm{bA}}$ & $119.27 \pm 4.40^{\mathrm{aA}}$ \\
GP & $332.19 \pm 10.19^{\mathrm{dB}}$ & $208.33 \pm 4.73^{\mathrm{cA}}$ & $143.54 \pm 3.70^{\mathrm{bA}}$ & $120.52 \pm 2.67^{\mathrm{aA}}$ \\
WEP & $421.35 \pm 4.45^{\mathrm{dC}}$ & $229.06 \pm 3.98^{\mathrm{cB}}$ & $199.79 \pm 6.63^{\mathrm{bC}}$ & $170.21 \pm 8.41^{\mathrm{aB}}$ \\
EEP & $484.17 \pm 4.98^{\mathrm{dD}}$ & $263.55 \pm 2.39^{\mathrm{cC}}$ & \\
\hline
\end{tabular}

${ }^{1)} \mathrm{CO}$, not added Panax ginseng sprout; GP, added grind Panax ginseng sprout; WEP, added low temperature $\left(50 \pm 3^{\circ} \mathrm{C}\right)$ extract of Panax ginseng sprout; EEP, added enzyme hydrolyzed extract of Panax ginseng sprout.

2)a-d Means with different superscripts within the same row are significantly different by Duncan's multiple range test $(p<0.05)$.

${ }^{3) A-D}$ Means with different superscripts within the same column are significantly different by Duncan's multiple range test $(p<0.05)$ 
Table 6. Changes in total phenolic compounds content of fermented wine added with Panax ginseng sprout from different pre-treatment condition

\begin{tabular}{|c|c|c|c|c|}
\hline \multirow{2}{*}{ Sample code ${ }^{1)}$} & \multicolumn{4}{|c|}{ Fermentation periods (days) } \\
\hline & 0 & 2 & 4 & 6 \\
\hline $\mathrm{CO}$ & $29.15 \pm 0.11^{\mathrm{a} 2) A 3)}$ & $35.02 \pm 0.70^{\mathrm{bAB}}$ & $36.14 \pm 1.30^{\mathrm{bcB}}$ & $37.19 \pm 0.56^{\mathrm{c}}$ \\
\hline GP & $30.67 \pm 0.21^{\mathrm{AB}}$ & $33.29 \pm 1.40^{\mathrm{bA}}$ & $35.07 \pm 0.88^{\mathrm{cAB}}$ & $35.30 \pm 0.10^{c}$ \\
\hline WEP & $32.35 \pm 2.82^{\mathrm{aBC}}$ & $34.24 \pm 0.90^{\mathrm{abAB}}$ & $34.27 \pm 0.70^{\mathrm{abA}}$ & $35.36 \pm 0.95^{b}$ \\
\hline EEP & $34.11 \pm 0.88^{\mathrm{aC}}$ & $35.50 \pm 1.92^{\mathrm{aB}}$ & $35.27 \pm 0.52^{\mathrm{bAB}}$ & $37.73 \pm 0.83^{\mathrm{c}}$ \\
\hline
\end{tabular}

${ }^{1)} \mathrm{CO}$, not added Panax ginseng sprout; GP, added grind Panax ginseng sprout; WEP, added low temperature $\left(50 \pm 3^{\circ} \mathrm{C}\right)$ extract of Panax ginseng sprout; EEP, added enzyme hydrolyzed extract of Panax ginseng sprout.

2)ac-Ceans with different superscripts within the same row are significantly different by Duncan's multiple range test $(\mathrm{p}<0.05)$.

${ }^{3) A-C}$ Means with different superscripts within the same column are significantly different by Duncan's multiple range test $(\mathrm{p}<0.05)$.

많이 검출되었고, 다음으로 $\mathrm{Rg} 1, \mathrm{Rh} 1, \mathrm{Rg} 3$ 순서로 많이 검출되었다. 백삼의 경우 진세노사이드 $\operatorname{Rg} 1$ 이 가장 많이 검출되고, 다음으로 $\mathrm{Re}, \mathrm{Rb} 2, \mathrm{Rf}, \mathrm{Rd}$ 순서로 많은 량의 진세 노사이드가 검출이 되는 것으로 보고되어 있는데(37) 본 연구의 결과와 비교할 때 그 함량에는 차이가 있었지만 $\mathrm{Re}$ 와 $\operatorname{Rg} 1$ 이 주요 진세노사이드로 동일한 경향이었다.

가장 함량이 높았던 $\operatorname{Re}$ 는 숙성 0 일 차에 24.86-34.30 $\mathrm{mg} / \mathrm{L}$ 이던 것이 숙성 6 일에는 $20.06-28.72 \mathrm{mg} / \mathrm{L}$ 의 범위였는
데, 새싹삼 분쇄물 첨가군(GP)과 새싹삼 효소분해 추출물 첨가군 $(\mathrm{EEP})$ 에서는 함량이 감소하는 경향이었으나 새싹삼 저온 추출물 첨가군(WEP)에서는 숙성 기간에 따른 Re의 함량은 유의적인 차이가 없었다. 다음으로 함량이 높았던 $\mathrm{Rg} 1$ 의 경우도 $\mathrm{Re}$ 와 동일한 변화의 경향을 보였으며, 숙성 0 일에 17.71-21.63 mg/L이던 것이 숙성 6 일후에는 $14.89-18.13 \mathrm{mg} / \mathrm{L}$ 의 범위로 검출되었다.

이와 같은 진세노사이드 함량의 감소는 진세노사이드의

Table 7. Changes in ginsenosides content of fermented wine added with Panax ginseng sprout from different pre-treatment condition

\begin{tabular}{|c|c|c|c|c|c|c|c|c|c|}
\hline \multirow{2}{*}{$\begin{array}{l}\text { Sample } \\
\text { code }\end{array}$} & \multirow{2}{*}{$\begin{array}{l}\text { Fer. period } \\
\text { (days) }\end{array}$} & \multicolumn{8}{|c|}{ Ginsenosides } \\
\hline & & $\operatorname{Re}$ & $\mathrm{Rg} 1$ & $\mathrm{Rf}$ & $\mathrm{Rh} 1$ & $\mathrm{Rb} 2$ & $\mathrm{Rd}$ & Rg3 & Total \\
\hline \multirow{4}{*}{$\mathrm{CO}$} & 0 & - & - & - & - & - & - & - & - \\
\hline & 2 & - & - & - & - & - & - & - & - \\
\hline & 4 & - & - & - & - & - & - & - & - \\
\hline & 6 & - & - & - & - & - & - & - & - \\
\hline \multirow{4}{*}{ GP } & 0 & $34.30 \pm 0.54^{(2)(3)}$ & $20.35 \pm 2.11^{\mathrm{cAB}}$ & $0.28 \pm 0.02^{\mathrm{bB}}$ & $7.72 \pm 0.59^{\mathrm{bB}}$ & - & $0.13 \pm 0.02^{\mathrm{A}}$ & $1.03 \pm 0.02^{\mathrm{aA}}$ & $63.83 \pm 3.30^{\mathrm{CB}}$ \\
\hline & 2 & $29.25 \pm 1.54^{\mathrm{bNS4})}$ & $18.53 \pm 0.55^{\mathrm{bcB}}$ & $0.16 \pm 0.01^{\mathrm{a}}$ & $4.68 \pm 1.25^{\mathrm{aA}}$ & - & - & $3.94 \pm 0.58^{\mathrm{bB}}$ & $56.56 \pm 3.92^{\text {bNS }}$ \\
\hline & 4 & $27.33 \pm 1.03^{\mathrm{abB}}$ & $16.40 \pm 0.44^{\mathrm{abNS}}$ & - & $6.31 \pm 0.80^{\mathrm{abNS}}$ & - & - & $1.53 \pm 0.11^{\mathrm{aNS}}$ & $51.57 \pm 2.37^{\mathrm{abNs}}$ \\
\hline & 6 & $26.19 \pm 0.86^{\mathrm{aB}}$ & $15.22 \pm 0.44^{\mathrm{aA}}$ & - & $6.07 \pm 0.79^{\mathrm{abA}}$ & - & - & $1.23 \pm 0.61^{\mathrm{aNS}}$ & $48.71 \pm 2.70^{\mathrm{aAB}}$ \\
\hline \multirow{4}{*}{ WEP } & 0 & $24.86 \pm 1.03^{\mathrm{NSA}}$ & $17.71 \pm 0.56^{\mathrm{NSA}}$ & $0.07 \pm 0.01^{\mathrm{A}}$ & $6.14 \pm 0.09^{\mathrm{NSA}}$ & - & $0.05 \pm 0.00^{\mathrm{A}}$ & - & $48.83 \pm 1.69^{\mathrm{VSA}}$ \\
\hline & 2 & $25.73 \pm 8.99$ & $14.52 \pm 0.70^{A}$ & - & $6.84 \pm 1.35^{\mathrm{AB}}$ & - & - & $2.48 \pm 0.64^{\mathrm{bA}}$ & $49.57 \pm 11.68$ \\
\hline & 4 & $28.63 \pm 3.42^{\mathrm{B}}$ & $14.61 \pm 3.88$ & - & $7.42 \pm 0.78$ & - & - & $1.86 \pm 0.34^{\mathrm{b}}$ & $52.52 \pm 8.41$ \\
\hline & 6 & $28.72 \pm 2.34^{\mathrm{B}}$ & $14.89 \pm 1.78^{\mathrm{A}}$ & - & $7.09 \pm 0.09^{B}$ & - & - & $0.79 \pm 0.00^{\mathrm{a}}$ & $51.49 \pm 4.21^{\mathrm{B}}$ \\
\hline \multirow{4}{*}{ EEP } & 0 & $30.52 \pm 1.11^{\mathrm{cB}}$ & $21.63 \pm 1.27^{\mathrm{bB}}$ & - & $8.24 \pm 0.49^{\mathrm{cB}}$ & $1.53 \pm 0.01^{\mathrm{c}}$ & $0.83 \pm 0.07^{\mathrm{bB}}$ & $2.87 \pm 0.46^{\mathrm{bB}}$ & $65.62 \pm 3.42^{\mathrm{cB}}$ \\
\hline & 2 & $24.12 \pm 1.06^{b}$ & $19.24 \pm 1.28^{\mathrm{abB}}$ & - & $7.83 \pm 0.36^{\mathrm{CB}}$ & $1.35 \pm 0.06^{b}$ & $0.75 \pm 0.06^{b}$ & $1.49 \pm 0.01^{\mathrm{aA}}$ & $54.78 \pm 2.83^{\mathrm{b}}$ \\
\hline & 4 & $20.42 \pm 1.98^{\mathrm{aA}}$ & $19.20 \pm 1.41^{\mathrm{ab}}$ & - & $6.87 \pm 0.42^{b}$ & $0.41 \pm 0.04^{\mathrm{a}}$ & $0.06 \pm 0.00^{\mathrm{a}}$ & - & $46.95 \pm 3.85^{\mathrm{a}}$ \\
\hline & 6 & $20.06 \pm 1.06^{\mathrm{aA}}$ & $18.13 \pm 1.19^{\mathrm{aB}}$ & - & $6.09 \pm 0.12^{\mathrm{aA}}$ & $0.35 \pm 0.09^{\mathrm{a}}$ & $0.06 \pm 0.01^{\mathrm{a}}$ & - & $44.69 \pm 2.47^{\mathrm{aA}}$ \\
\hline
\end{tabular}

${ }^{1)} \mathrm{CO}$, not added Panax ginseng sprout; GP, added grind Panax ginseng sprout; WEP, added low temperature $\left(50 \pm 3^{\circ} \mathrm{C}\right)$ extract of Panax ginseng sprout; EEP, added enzyme hydrolyzed extract of Panax ginseng sprout.

2)ac- Means with different superscripts within the same sample code are significantly different by Duncan's multiple range test $(\mathrm{p}<0.05)$.

${ }^{3) A-B}$ Means with different superscripts within the same fermentation day are significantly different by Duncan's multiple range test $(\mathrm{p}<0.05)$.

${ }^{4) \mathrm{NS}}$ Means no significantly difference. 
본래의 성질에 의한 것으로 진세노사이드는 유기산과 효소 등에 의해 분해되어 작은 분자량의 진세노사이드로 변화하 는 특징이 있는데 진세노사이드의 당과 물분자의 제거 정도 에 따라 구조 및 성상이 달라지며, 고분자에서 저분자로 변형됨에 따라 약리적 활성도 바뀌게 된다(17). 예를 들어 protopamaxaiol(PPD) 계열인 진세노사이드 $\mathrm{Rb} 1$ 의 경우 20 번 탄소에 연결된 두 개의 glucose 중 하나가 제거되면 진세 노사이드 $\mathrm{Rd}$ 가 되며, 진세노사이드 $\mathrm{Rd}$ 에서 glucose 하나가 더 제거되면 진세노사이드 $\mathrm{Rg} 3$ 가 형성된다(15). 새싹삼 막 걸리에 다량 함유되어 있는 ginsenosie Re와 $\operatorname{Rg} 1$ 은 비교적 큰 분자의 진세노사이드에 속하므로 발효주의 숙성이 진행 됨에 따라 증가한 유기산에 의해서 분해됨으로 인해 숙성 기간이 경과할수록 그 함량이 감소된 것으로 생각된다.

숙성 기간의 경과에 따른 진세노사이드의 총량은 WEP 군에서는 유의적인 변화가 없었으나 GP군과 $\mathrm{EEP}$ 군에서는 유의적으로 감소하여 숙성 6 일에 잔존율은 각각 $76.3 \%$ 와 $68.1 \%$ 로 $\mathrm{EEP}$ 군에서 감소폭이 더 컸다.

$\operatorname{Kim}$ 등(38)은 진세노사이드가 효소의 영향을 받아 가수 분해가 진행된다고 하였는데, 진세노사이드의 감소가 가장 많은 EEP군의 경우 숙성 초기부터 환원당 함량이 높아 효모 의 증식에 유리한 환경을 제공함에 따라 효모가 생성한 효소의 양이 증가됨으로 인해 진세노사이드의 가수분해를 촉진한 결과로 추정된다.

상대적으로 다량 함유된 Re, Rg1, 및 Rh1을 제외한 진세 노사이드는 일부 시료에서는 검출되지 않거나 숙성기간의 경과에 따라 생성 또는 소실되었다. 즉, Rg3의 경우 GP군에 서는 숙성 2 일에 $3.94 \mathrm{mg} / \mathrm{L}$ 로 가장 함량이 높았다가 이후에 는 점차 감소하였으며, WEP군에서는 숙성 2 일에 $2.48 \mathrm{mg} / \mathrm{L}$ 으로 처음 검출되었고, $\mathrm{EEP}$ 군에서는 숙성 0 일에 $2.87 \mathrm{mg} / \mathrm{L}$ 이 검출되었으나 그 함량이 감소하여 숙성 4 일부터는 검출 되지 않았다. $\mathrm{Rd}$ 의 경우 $\mathrm{GP}$ 군과 $\mathrm{WEP}$ 군에서는 숙성이 진행 되면서 검출되지 않았으나 $\mathrm{EEP}$ 군에서는 $0.06-0.83 \mathrm{mg} / \mathrm{L}$ 의 범위에서 전 숙성 기간 동안 검출되었다. $\mathrm{Rb} 2$ 는 $\mathrm{EEP}$ 군에서 만 $0.35-1.53 \mathrm{mg} / \mathrm{L}$ 범위에서 검출되었으며 $\mathrm{Rf}$ 는 $\mathrm{GP}$ 군에서
는 숙성 2 일까지, $\mathrm{WEP}$ 군에서는 숙성 0 일 차에만 검출되었 으며, $\mathrm{EEP}$ 군에서는 검출되지 않았다. 이러한 진세노사이드 의 함량 차이는 숙성 0 일 차를 기준으로 볼 때 첨가된 새싹 삼의 전처리 과정이 서로 상이하기 때문에 이후 발효주의 숙성 과정에서 진세노사이드의 분해와 전환에 영향을 미쳤 기 때문으로 추정된다.

\section{숙성 중 항산화활성의 변화}

$\mathrm{ABTS}$ 를 이용한 라디칼 소거활성 측정법은 수소공여항 산화제(hydrogen donating antioxidant)와 연쇄 절단형 항산 화제(chain breaking antioxidant)를 모두 측정할 수 있고, 수용상(aqueous phase)과 유기상(organic phase) 모두에 적 용이 가능한 장점이 있다 $(21,39)$.

전처리 방법을 달리한 새싹삼 첨가 발효주의 숙성 동안 $\mathrm{ABTS}$ 라디칼 소거활성의 변화는 Table 8과 같다. 숙성 0일 차의 ABTS 라디칼 소거활성은 53.08-57.89\%의 범위이던 것이 숙성 기간의 경과와 더불어 점차 증가하여 숙성 6 일에 는 62.64-64.71\%의 범위로 시료 간에 유의적인 차이는 없었 다. 이는 $\mathrm{Kim}$ 등(25)의 논문 설기떡을 이용한 흑마늘 막걸리 의 제조와 품질 특성에서 발효주의 숙성기간이 경과함에 따라 $\mathrm{ABTS}$ 라디칼 소거활성이 높아지는 것과 같은 결과였 다.

Cho 등(26)은 총 페놀, 플라보노이드 및 안토시아닌의 함량이 높을수록 $\mathrm{ABTS}$ 라디칼 소거활성이나 환원력과 같 은 항산화 활성이 높다고 보고하였는데, 이는 본 연구의 결과에서도 동일한 경향으로 총 페놀 화합물의 증가폭이 상대적으로 높은 숙성 2-4일의 시료에서 ABTS 라디칼 소거 활성이 더 높았다.

\section{요 약}

새싹삼의 유효성분 및 진세노사이드를 함유한 발효주 제조를 위해 3 단계로 나누어 각 2 일씩 발효 증량하면서

Table 8. Changes in ABTS radical scavenging activity of fermented wine added with Panax ginseng sprout from different pre-treatment condition

$(\%)$

\begin{tabular}{ccccc}
\hline \multirow{2}{*}{ Sample code ${ }^{\mathrm{l})}$} & \multicolumn{4}{c}{ Fermentation periods (days) } \\
\cline { 2 - 5 } & 0 & 2 & $63.00 \pm 2.46^{\mathrm{cB}}$ & 6 \\
\hline CO & $54.62 \pm 1.63^{\mathrm{a} 2) \mathrm{AB})}$ & $59.96 \pm 0.58^{\mathrm{bB}}$ & $61.75 \pm 0.65^{\mathrm{cAB}}$ & $63.52 \pm 0.47^{\mathrm{dA}}$ \\
GP & $53.08 \pm 0.31^{\mathrm{aA}}$ & $58.22 \pm 0.56^{\mathrm{bA}}$ & $60.05 \pm 0.57^{\mathrm{bA}}$ & $62.64 \pm 0.43^{\mathrm{cA}}$ \\
WEP & $56.61 \pm 0.36^{\mathrm{aB}}$ & $56.73 \pm 0.46^{\mathrm{aA}}$ & $63.83 \pm 0.92^{\mathrm{cB}}$ & $64.71 \pm 0.96^{\mathrm{cA}}$ \\
EEP & $57.89 \pm 1.22^{\mathrm{aB}}$ & $61.42 \pm 1.83^{\mathrm{bB}}$ & \\
\hline
\end{tabular}

${ }^{1)} \mathrm{CO}$, not added Panax ginseng sprout; GP, added grind Panax ginseng sprout; WEP, added low temperature $\left(50 \pm 3^{\circ} \mathrm{C}\right)$ extract of Panax ginseng sprout; EEP, added enzyme hydrolyzed extract of Panax ginseng sprout.

2)-c-Ceans with different superscripts within the same row are significantly different by Duncan's multiple range test $(\mathrm{p}<0.05)$.

${ }^{3) A-B}$ Means with different superscripts within the same column are significantly different by Duncan's multiple range test $(p<0.05)$ 
발효주를 제조 한 후 전처리 방법을 달리한 새싹삼 $(\mathrm{CO}$, 무첨가 대조군; GP 새싹삼 분쇄물 첨가; WEP, 새싹삼 물 추출물; $\mathrm{EEP}$, 새싹삼 효소분해 추출물)을 발효주의 총 무게 대비 6\%씩 함유하도록 첨가하여 6일간 숙성시키면서 이화 학적 특성을 분석하였다. 3 단계까지의 담금 과정에서 알코 올 함량은 담금 단계가 이어질수록 높아졌으며, $\mathrm{pH}$ 는 낮아 지고, 산도는 증가하는 경향이었다. 3 단계 담금 후 6 일간의 숙성 동안 알코올 함량은 서서히 높아졌으며, $\mathrm{pH}$ 는 서서히 낮아지고 산도가 증가하였다. 숙성 6일 동안 환원당 함량은 감소하는 경향이었는데, 특히 숙성 2 일에 급격하게 함량이 감소하였다. 총페놀화합물의 함량은 숙성이 진행됨에 따라 점차 증가하는 경향이었다. 발효주의 숙성 중 진세노사이 드는 Re가 가장 높은 함량이었으며 다음으로 Rg1과 Rh1의 순으로 함량이 높았고, 그 외의 진세노사이드는 일부 시료 에서만 검출되었으며, 그 함량도 낮았다. 숙성 초기의 진세 노사이드 함량은 GP와 EEP가 WEP에 비해 더 높았으나 숙성기간의 경과와 더불어 점차 감소하여 숙성 6 일후에는 WEP에서 총진세노사이드의 함량이 가장 높았다. 숙성기 간 중 $\mathrm{ABTS}$ 라디칼 소거활성은 숙성 기간의 경과와 더불어 증가하는 경향이었으며, 숙성 6일에는 62.64-64.71\%로 서 로 간에 유의적인 차이가 없었다. 이상의 결과로부터 볼 때 담금이 진행 된 후 첨가된 새싹삼은 전처리 방법에 관계 없이 발효주의 기초 품질에는 영향을 미치지 않았으나 진세 노사이드 함량을 기준으로 볼 때 $50^{\circ} \mathrm{C}$ 정도의 저온에서 추출한 물추출물을 첨가하는 것이 가장 적절할 것으로 판단 된다.

\section{감사의 글}

본 논문은 중소기업벤쳐부의 지역주력산업육성사업 창 의융합 R\&D 과제(R0006093) 수행에 따른 연구 성과의 일 부이며 이에 감사드립니다.

\section{References}

1. Ko SR, Choi KJ, Kim YH (1996) Comparative study on the essential oil components of Panax species. Korean J Ginseng Sci, 20, 42-48

2. Min JY, Kim NY, Kim US, Han MJ (2015) The quality characteristics of pasteurized ginseng Makgeolli added with different concentration of ginseng powder. Korean J Korean Soc Food Cult, 30, 757-765

3. Nam KY (2002) Clinical applications and efficacy of Korean ginseng (Panax ginseng C.A. Meyer). J Ginseng Res, 26, 111-131
4. Kim D, Kim KH, Yook HS (2014) Quality characteristics of cookies added with ginseng leaf. Korean J Food Cook Sci, 30, 679-686

5. Cabral de Oliveira AC, Perez AC, Merino G, Prieto JG, Alvarez AI (2001) Protective effects of Panax ginseng on muscle injury and inflammation after eccentric exercise. Comp Biochem Physiol C Toxicol Pharmacol, 130, 369-377

6. Chang HK (1998) Changes of saponin contents in Panax ginseng leaves by different harvesting months. Korean J Food Nutr, 11, 82-86

7. Chang HK (2003) Effect of processing methods on the saponin contents of Panax ginseng leaf-tea. Korean J Food Nutr, 16, 46-53

8. Cho SH (1977) Saponins of Korean ginseng CA Meyer (Part II): the saponins of the ground part of ginseng. J Korean Agric Chem Soc, 20, 142-146

9. Horticultural industry. Ministry of agriculture (2014) Ginseng collection of statistics in 2013. No. 11-1543000-000004-10

10. Park MY (2017) A study on the optimization of wild-simulated ginseng in the forest. MS Thesis, Silla University, Korea, p 1-2

11. Jang IB, Yu J, Suh SJ, Jang IB, Kwon KB (2018) Growth and ginsenoside content in different parts of ginseng sprouts depending on harvest time. Korean J Med Crop Sci, 26, 205-213

12. Kim KP, Kim KH, Yook HS (2016) Quality characteristics of castella with Panax ginseng sprout powder. J Korean Soc Food Sci Nutr, 45, 711-716

13. Jung HB, Seoung TJ, Kim JG (2017) Quality characteristics of sprout ginseng paste added dry oyster and dry shrimp. Culinary Sci Hospitality Res, 23, 206-215

14. Lee JH, Cho SH, Yun MY, An SK, Jang HH, Lee SN, Song GY (2015) Anti-wrinkle effect of rare ginsenosides, produced from ginsenoside Rd. Korean J Aesthetic Cosmetol, 13, 909-916

15. Kim SD, Seu JH (1982) Conversion of ginseng saponin with the enzyme produced by Rhizopus sp. (part 1): confirmation of conversion of ginsenoside-Rb1 to ginsenoside-Rd. Korean J Appl Microbiol Bioeng, 10, 267-273

16. So MH, Lee YS, Han SH, Noh WS (1999) Analysis of major flavor compounds in Takju mash brewed with a modified Nuruk Korean J Food Nutr, 12, 421-426

17. Ko SK, Lee KH, Hong JK, Kang SA, Sohn UD, Im BO, Han ST, Yang BW, Chung SH, Lee BY (2005) 
Change of ginsenoside composition in ginseng extract by vinegar process. Food Sci Biotechnol, 14, 509-513

18. NTSTSI (2005) Manufacturing guideline of Takju and Yakju. National Tax Service Technical Service Institute. Seoul, Korea, p 195-198

19. Gutfinger T (1981) Polyphenols in olive oils. J Am Oil Chem Soc, 58, 966-968

20. Blois MS (1958) Antioxidant determinations by the use of a stable free radical. Nature, 181, 1199-1200

21. Re R, Pellegrini N, Proteggente A, Pannala A, Yang M, Rice EC (1999) Antioxidant activity applying an improved ABTS radical cation decolorization assay. Free Radical Biol Med, 26, 1231-1237

22. Jang JH (1989) History of Korean traditional rice wine. Korean J Diet Cult, 4, 271-274

23. So MH, Lee YS, Noh WS (1999) Changes in microorganisms and main components during Takju brewing by a modified Nuruk Korean J Food Nutr, 12, 226-232

24. Lee HS, Park CS, Choi JY (2010) Quality characteristics of the mashes of Takju prepared using different yeasts. Korean J Food Sci Technol, 42, 56-62

25. Kim GM, Jung WJ, Shin JH, Kang MJ, Sung NJ (2011) Preparation and quality characteristics of Makgeolli made with balck garlic extract and Sulgidduk J Korean Soc Food Sci Nutr, 40, 759-766

26. Cho HK, Lee JY, Seo WT, Kim MK, Cho KM (2012) Quality characteristics and antioxidant effects during Makgeolli fermentation by purple sweet potato-rice Nuruk Korean J Food Sci Technol, 44, 728-735

27. Kim CJ (1963) Studies on the quantitative changes of organic acid and sugars during the fermentation of Takju. Appl Biol Chem, 4, 33-42

28. Kim SY, Kim EK, Yoon SJ, Jo NJ, Jung SK, Kwon SH, Chang YH, Jeong YH (2011) Physicochemical and microbial properties of Korean traditional rice wine, makgeolli, supplemented with cucumber during fermentation. J Korean Soc Food Sci Nutr, 40, 223-228

29. Lee MK, Lee SW, Yoon TH (1994) Quality assessment of Yakju brewed with conventional Nuruk J Korean Soc Food Sci Nutr, 23, 78-89
30. Lee JO, Kim CJ (2011) The influence of adding buckwheat sprouts on the fermentation characteristics of Yakju. J Korean Soc Food Cult, 26, 72-79

31. So MH, Lee Y, Noh WS (1999) Improvement in the quality of takju by a modified nuruk Korean J Food Nutr, 12, 427-432

32. Lee TJ, Hwang DY, Lee CY, Son HJ (2009) Changes in yeast cell number, total acid and organic acid during production and distribution processes of Makgeolli, traditional alcohol of Korea. Korean J Microbiol, 45, 391-396

33. Park EY, Kim JY, Jeong SM, Lee DH (2014) Characteristics of enzymatic hydrolysis of microcrystalline cellulose and Laminaria japonica. J Korea Soc Waste Manage, 31, 820-832

34. Park JH, Bae SM, Yook C, Kim JS (2004) Fermentation characteristics of Takju prepared with old rice. Korean J Food Sci Technol, 36, 609-615

35. Cai Y, Luo Q, Sun M, Corke H (2004) Antioxidant activity and phenolic compounds of 112 traditional Chinese medicinal plants associated with anticancer. Life Sci, 74, 2157-2184

36. Budak HN, Guzel Seydim ZB (2010) Antioxidant activity and phenolic content of wine vinegars produced by two different techniques. J Sci Food Agric, 90, 2021-2026

37. Sun BS, Gu LJ, Fang ZM, Wang CY Wang Z, Lee MR, Li Z, Li JJ, Sung CK (2009) Simultaneous quantification of 19 ginsenosides in black ginseng developed from Panax ginseng by HPLC-ELSD. J Pharm Biomed Anal, $50,15-22$

38. Kim JH, Han IH, Yamabe N, Kim YJ, Lee W, Eom DW, Choi P, Cheon GJ, Jang HJ, Kim SN, Han J, Kang KS (2014) Renoprotective effects of maillard reaction products generated during heat treatment of ginsenoside Re with leucine. Food Chem, 143, 114-121

39. Jeon MH, Lee WJ (2011) Characteristics of blueberry added Makgeolli. J Korean Soc Food Sci Nutr, 40, 444-449 